\title{
USE OF ION EXCHANGE FOR REMOVAL OF AMMONIUM: A BIOLOGICAL REGENERATION OF ZEOLITE
}

A.R. RAHMANI ${ }^{*}$

A.H. MAHVI ${ }^{2}$

Received: 30/5/2005

Accepted: 15/2/2006

\author{
${ }^{1}$ Hamadan University of Medical Sciences \\ Environmental Health Department, Hamadan, Iran \\ ${ }^{2}$ Tehran University of Medical Sciences \\ Environmental Eng. Department, Tehran, Iran
}

*to whom all correspondence should be addressed: e-mail:rah1340@yahoo.com

\begin{abstract}
Nitrogen in the Ammonia form can have deleterious effects in water resources. Ion Exchange by zeolite and biological Nitrification processes are two proposed methods for removing Nitrogen compounds from wastewater and effluents. The main objective of this research was to investigate the efficiency of nitrifying bacteria for regenerating Clinoptilolite zeolite.

In this research, the Semnan Clinoptilolite zeolite was supplied in mesh 30 . Then the capacity of zeolite in ammonium removal was determined in column system.

To cultivate of nitrifying bacteria a sludge sample was taken from a domestic wastewater treatment plant and added to a $15 \mathrm{I}$ aeration tank. Ammonium and other nutrients were added in the reactor daily over a month period and the effect of nitrate anion and MLVSS on nitrification process have been determined. After saturation of zeolite with ammonium, biological regeneration was done by contact of zeolite and nitrifying bacteria in column system. In this stage slurry of nitrifying bacteria is pumped up flow through the zeolite column and recycled to the aeration tank. The effluent containing the displaced ammonium is oxidized to nitrate by the nitrifying bacteria. Then the nitrified brine is clarified in a sedimentation tank and stored for reuses.

The results showed that the cation exchange capacity was 10.06 (in breakthrough point) and $18.38 \mathrm{mg} \mathrm{NH}_{4}{ }^{+} \mathrm{g}^{-1}$ zeolite as total capacity. The results indicated that nitrification accelerated by increasing in MLVSS concentration and concentration of nitrate remains in solution. The results obtained from bioregeneration tests of zeolite showed that the efficiency was 87.7 to $99.8 \%$ in period of 3.5 to 5.5 hours.

Based on the results, since regeneration is achieved in high concentration of nitrate, the use of nitrifying sludge in several cycles is possible and the use of system can be appreciated to an alternative economical method for removing $\mathrm{NH}_{4}{ }^{+}$from effluent.
\end{abstract}

KEYWORDS: Ammonium removal - Ion exchange - Zeolite - Nitrification - Biological regeneration

\section{INTRODUCTION}

Ammonia nitrogen compounds in the wastewaters and effluents have harmful effects on water resources [1]. The three most widely used methods for removal of ammonium from polluted water are air stripping, ion exchange with natural zeolite and biological nitrificationdenitrification [2]. Clinoptilolite is a natural zeolite that has been known for their ability to remove ammonium from polluted waters. The capacity of zeolite and chemical regeneration for ammonium removal was investigated in several studies [3-8]. Usually, the service cycle is a down flow packed bed column followed by chemical regeneration (usually by $\mathrm{NaCl}$ ). The major drawback of this process is the high cost of the chemical regeneration stage and disposal of the concentrated ammonium-sodium brain produced [9]. 
During the last years several investigators have been studied the biological regeneration of ion exchange systems [9-13]. These researches supported that the mechanism of regeneration is ion exchange and nitrification of displaced ammonium respectively. The process are carried out in two separate phase [9, 11, 12]:

1) Ion exchange stage: A column filled with zeolite is used for ammonium ion exchange from secondary effluent. When $\mathrm{NH}_{4}$ concentration breakthrough occurs, the bioregeneration stage after backwashing the bed started.

2) Bioregeneration stage: Biological regeneration has been done by contact of zeolite and nitrifying bacteria in column system. Thus the microorganisms can only oxidized ammonium released to solution, therefore, a cation containing solution is recirculated through the bed in order to desorb $\mathrm{NH}_{4}$ to the solution (equation 1).

$\mathrm{Z}-\mathrm{NH}_{4}^{+}+\mathrm{Na}^{+} \leftrightarrow \mathrm{Z}-\mathrm{Na}^{+}+\mathrm{NH}_{4}^{+}$

The effluent containing the displaced ammonium is oxidized to nitrate by the nitrifying bacteria in aeration. Then the nitrified brine is clarified and stored for reuses. (equation 2).

$\mathrm{NH}_{4}^{+}+2 \mathrm{O}_{2} \rightarrow \mathrm{NO}_{3}^{-}+2 \mathrm{H}^{+}+\mathrm{H}_{2} \mathrm{O}$

The biological regeneration process will therefore result in the accumulation of brine. This nitrate brine is easy to dispose of. It may be mixed with raw wastewater and denitrified to harmless nitrogen gas. The purpose of this study was removal of ammonium from secondary effluent by clinoptilolite followed by bioregeneration.

\section{MATERIALS AND METHODS}

The system is composed of the following items: a column made of Plexiglas was $120 \mathrm{~cm}$ long with an internal diameter of $2.5 \mathrm{~cm}$; 1 feed pump; 1 centrifugal recirculation pump; $\mathrm{pH}$ meter; 15 liter container as aeration tank and air compressor. The clinoptilolite was obtained from Semnan mines at the north part of Iran. The samples were grounded and sieved based on U.S. standard mesh number 30 and conditioned by $0.25 \mathrm{M}$ ammonia sulfate and $1 \mathrm{M}$ sodium chloride respectivly [6]. The column filled with $30 \mathrm{~g}$ clinoptilolite and the bed volume obtained $36 \mathrm{ml}$. An ammonium chloride solution with $100 \mathrm{mg} \mathrm{l}^{-1}$ ammonium was applied to the column by gravity feed constant head device with 12 bed volume per hour. The ammonium content of the column effluent was measured with time. Service cycle was stopped when the ammonium concentration increased to $2 \mathrm{mg} \mathrm{l}^{-1}$. The breakthrough curve so obtained was used to calculate the capacity of the zeolite for ammonium exchange. A schematic of pilot is shown in fig. 1.

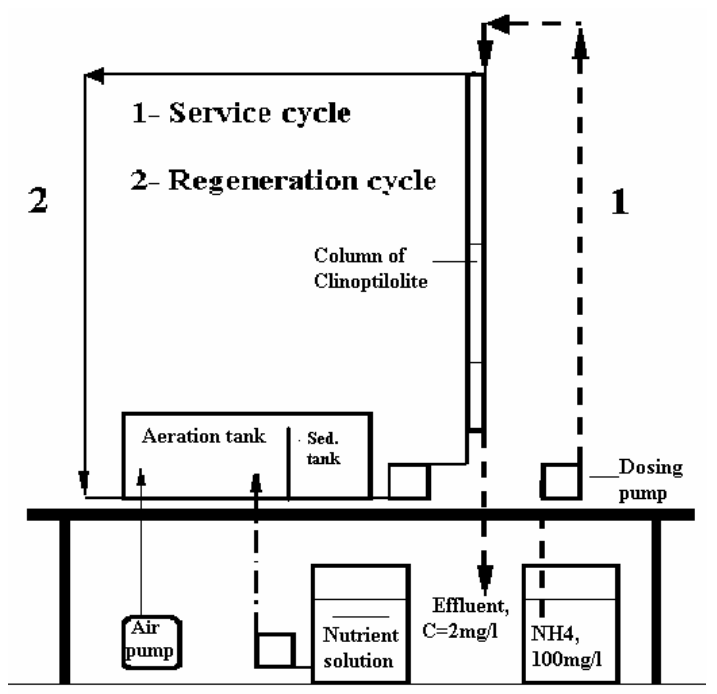

Figure 1. Schematic of designed pilot

\subsection{Culturing nitrifying bacteria and nitrification test}

The sludge sample from a wastewater treatment plant was used as a source of nitrifying bacteria. The volume of reactor for culturing of nitrifying bacteria was 15 liters. Nutrient solution was provided by dechlorinated water and following materials, carbonate and 
bicarbonate as source of $\mathrm{C}, \mathrm{K}_{2} \mathrm{HPO}_{4}$ as source of $\mathrm{K}$ and $\mathrm{P}, \mathrm{NaCl}$ as source of cation in regeneration period, other materials were $\mathrm{CaCO}_{3}, \mathrm{MgSO}_{4}$ and Ammonium-molibdate [11]. The source of nitrogen was Ammonium sulfate $\left(10\right.$ to $\left.120 \mathrm{mg} \mathrm{l}^{-1}\right)$. Initially, low concentration of ammonium was added to the reactor and over a five-week period the concentration of ammonium was increased to $120 \mathrm{mg} \mathrm{l}^{-1}$. as $\mathrm{N}$. The $\mathrm{pH}$ of reactor was controlled at 8.0 by addition of $1 \mathrm{M} \mathrm{Na}_{2} \mathrm{CO}_{3}$. The temperature of reactor was controlled at $29 \pm 2^{\circ} \mathrm{C}$ with an immersion heater. The oxygen of reactor was supplied with an air compressor at 2 to $3 \mathrm{mg} \mathrm{I}^{-1}$. concentrations. The rate of nitrification was determined by measured of ammonium concentration and volatile suspended solids content (MLVSS) of the aeration tank with time [11].

\subsection{Bioregeneration of zeolite}

In the beginning of bioregeneration mode, the column was backwash with water for 5 minutes at approximately 30 percent expansion and the feed of nutrient solution to aeration tank was stopped. The clinoptilolite was regenerated by recirculating a slurry through the column. The slurry was drawn from sedimentation tank, pumped upflow through the column and then recirculated to the aeration tank. A variable speed pump recirculated the effluent of $5 \mathrm{l} / \mathrm{hr}$. and fluidized the bed to $20 \%$ expansion. The slurry on contact with spent clinoptilolite the solution eluted ammonium ions which were transported to the aeration tank for the oxidation. The $\mathrm{pH}$ of the solution was regulated at $8 \pm 0.2$ with manual addition of $1 \mathrm{M} \mathrm{Na}_{2} \mathrm{CO}_{3}$. The ammonium content of the aeration tank was monitored with time after the start of regeneration. Regeneration was stopped when the ammonium concentration fell below $0.5 \mathrm{mg} \mathrm{l}^{-1}$. In certain interval time, The $\mathrm{NH}_{4}{ }^{+}$content of the reactor and the amount of base added for the maintenance of $\mathrm{pH}$ were measured. Then the column was backwash for 5 minutes at $30 \%$ expansion to ensure that all the slurry was removed from the column. After backwash the column was replaced in service. For determination of biological regeneration efficiency of zeolite for each test, the amount of ammonium removed from the zeolite was estimated by subtracting the amount of ammonium eluted from the total ammonium content of the saturated then by dividing the amount of ammonium removed from the Clinoptilolite by the total original ammonium content of the Clinoptilolite. All analysis were made according to the standard methods [14].

\section{RESULTES AND DISCUSSION}

\subsection{Characterization of Clinoptilolite}

The cation exchange capacity of the Semnan Clinoptilolite for ammonium was determined. The tests results on conditioned zeolite showed that the cation exchange capacity was 10.06 (in breakthrough point) and $18.38 \mathrm{mg} \mathrm{NH}_{4}{ }^{+} \mathrm{g}^{-1}$ zeolite as total capacity $(6,8)$. The results indicated that high level of regeneration (95-98\%) might be achieved with solution of $\mathrm{CINa}$ (table 1).

Table 1. Semnan clinoptilolite capacity measurements

\begin{tabular}{lc}
\hline Ammonium con., $\mathrm{C}_{0}, \mathrm{mg}^{-1}$ & 101 \\
\hline Breakthrough Capacity, $\mathrm{mg} \mathrm{NH}_{4} \mathrm{~g}^{-1}$ zeolite & 10.06 \\
\hline Total capacity, $\mathrm{mg} \mathrm{NH}_{4} \mathrm{~g}^{-1}$ zeolite & 18.38 \\
\hline Total ammonium adsorbed in column, $\mathrm{mg}$ & 551.4 \\
\hline Total ammonium realized in regeneration, $\mathrm{mg}$ & 558.37 \\
\hline
\end{tabular}

In culturing nitrifying bacteria and nitrification test the MLVSS concentration slowly rose from approximately 190 near to $630 \mathrm{mg} \mathrm{l}^{-1}$. The generated sludge was very flocculent and settled well. The $\mathrm{NH}_{4}{ }^{+}$ion concentration fed to the reactor $\left(120 \mathrm{mg} \mathrm{l}^{-1}\right.$.) was depleted to near zero within a matter of 4 to $6 \mathrm{hr}$.

For determination of $\mathrm{NH}_{4}{ }^{+}$stripping under the test condition prior to any nitrification test, $1 \mathrm{I}$. of distilled water content of $120 \mathrm{mg} \mathrm{l}^{-1}$. $\mathrm{NH}_{4}{ }^{+}$as $\mathrm{N}$ was held at $\mathrm{pH}=8$ and $30{ }^{\circ} \mathrm{C}$ and aerated. Long aeration time indicated an hourly $\mathrm{NH}_{4}$ loss of 0.95 to $1.12 \mathrm{mg} \mathrm{N}^{-1} \mathrm{hr}^{-1}$ [10]. Since the rates of nitrification in this study were very much greater than the rate of $\mathrm{NH}_{4}{ }^{+}$stripping were negligible [13]. The activity of the nitrifying sludge were measured as $\mathrm{mg} \mathrm{N}$ oxidized I$^{-1} \mathrm{hr}^{-1} \mathrm{mg}^{-1}$ MLVSS $^{-1}$ (fig. 2). 


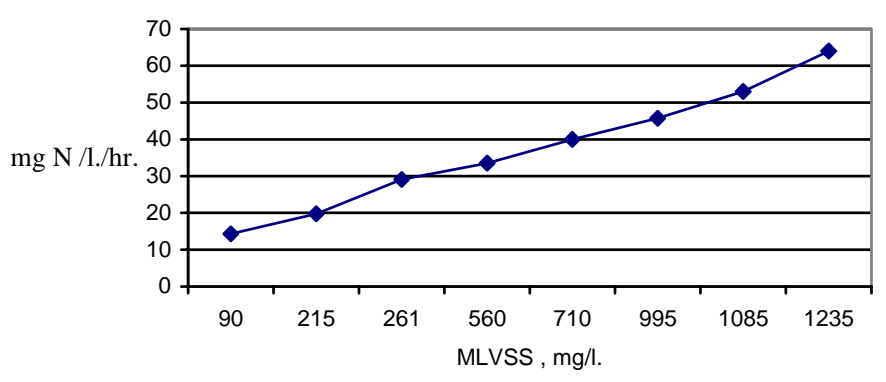

Figure 2. Influence of sludge concentration on rate of nitrification

The amount of base to control the $\mathrm{pH}$ in nitrification test was determined "1.47 to 1.86 " meq meq $^{-1}$ of ammonium oxidized. The amount of base added per meq of ammonium oxidized in stoichiometric equilibrium is 2 meq meq ${ }^{-1} \mathrm{NH}_{4}{ }^{+}$oxidized. It is probable that the stripping of $\mathrm{CO}_{2}$ during aeration may account for the remaining differences between the measured and stoichiometric base requirements. Since there was no relationship between the amounts of base added to the amount of $\mathrm{NH}_{4}{ }^{+}$oxidized, the rate of base addition could not be used to monitor the rate of nitrification with any accuracy [11]. The results of biological regeneration efficiency of zeolite showed 87.7 to $99.8 \%$ regeneration level achieved in a range of 3 to 5.5 $\mathrm{hr}$. depending upon the MLVSS concentration (table 2).

Table 2. The results of biological regeneration test of Clinoptilolite

\begin{tabular}{ccccccc}
\hline $\begin{array}{c}\text { Test } \\
\text { No. }\end{array}$ & $\begin{array}{c}\text { MLVSS, } \\
\left(\mathbf{m g ~ l}^{-1}\right)\end{array}$ & $\begin{array}{c}\text { Regeneration } \\
\text { time (hr) }\end{array}$ & $\begin{array}{c}\text { Eluted NH } \\
(\mathbf{m g})\end{array}$ & $\begin{array}{c}\text { Nitrate } \\
\text { produce } \\
(\mathbf{m g})\end{array}$ & $\begin{array}{c}\text { Oxidized N } \\
\left(\mathbf{m g ~ N ~ I}^{-1} \mathbf{h r}^{-1}\right)\end{array}$ & $\begin{array}{c}\text { Efficiency } \\
(\%)\end{array}$ \\
\hline 1 & 817 & 3.75 & 531.32 & 1830 & 9.18 & 96.36 \\
\hline 2 & 654 & 5 & 510.65 & 1759 & 6.59 & 92.61 \\
\hline 3 & 712 & 4.25 & 536.95 & 1849 & 8.19 & 97.38 \\
\hline 4 & 519 & 5.5 & 494.17 & 1702 & 5.82 & 89.62 \\
\hline 5 & 649 & 4.75 & 527.47 & 1817 & 7.2 & 95.66 \\
\hline 6 & 878 & 3.5 & 544 & 1874 & 10.07 & 98.66 \\
\hline 7 & 545 & 5.5 & 514.13 & 1771 & 6.06 & 93.24 \\
\hline 8 & 935 & 3.25 & 547.65 & 1886 & 10.92 & 99.32 \\
\hline 9 & 723 & 4.25 & 483.96 & 1667 & 7.38 & 87.77 \\
\hline 10 & 955 & 3 & 550.3 & 1895 & 11.89 & 99.8 \\
\hline
\end{tabular}

In figure 3 that plotted from data in table 2 the rate of nitrification measured as $\mathrm{mg} \mathrm{N}$ oxidized $\mathrm{I}^{-1} \mathrm{hr}^{-1}$ is plotted vs. the concentration of MLVSS.

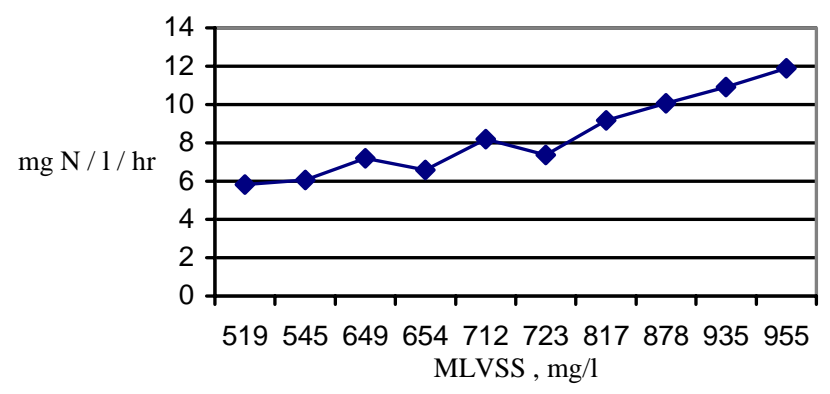

Figure 3. Influence of sludge concentration rate on bioregeneration

The results obtained from bioregeneration studies have clearly shown that the regeneration of saturated Clinoptilolite with ammonium through the use of nitrifying bacteria is possible [7, 9, 10]. This process is rapid and time required for regeneration depends very much upon the nitrifying activity of the sludge used. Fig 3 shown the amount of ammonium oxidized per hour vs. MLVSS in regeneration period. This figure is analogous to figure 2 calculated for the nitrification tests. From figures 2 and 3 the rate of nitrification is much slower during 
regeneration than it is when the ammonium is present in free solution. In the bioregeneration the ammonium ions within the crystalline cages of the zeolites are not accessible to nitrifying bacteria. For the oxidation of $\mathrm{NH}_{4}{ }^{+}$ion, it must first diffuse to the particle surface or into solution where it becomes accessible to the bacteria. The relation between ammonium ion concentration in solution and variation for MLVSS concentration indicated that, the use of higher sludge concentration resulted in the displacement of higher ammonium concentration from the zeolite [11]. The higher MLVSS concentrations content the higher ambient salt concentration and thus encouraged the exchange displacement of ammonium ions and resulted in the higher solution concentration observed. So the result obtained from the influence of salt concentration in nitrification period indicated that the rate of regeneration increased with salt concentration [9].

The ion exchange process has the advantages such as high reaction rate, good control of effluent quality and no sensitivity to fluctuation in $\mathrm{NH}_{4}^{+}$influent concentration. Also regeneration is achieved in high concentration of nitrate. Thus the use of system can be appreciated to an alternative economical removal of $\mathrm{NH}_{4}{ }^{+}$from effluent.

\section{ACKNOWLEDGMENT}

We gratefully acknowledge financial support for this project from the Environmental Health Dept., Faculty of Health, Hamadan University of Medical sciences. We would also like to thank Eng $\mathrm{H}$. Ehsani for his Co. operation during the study.

\section{REFRENCES}

1. U.S.EPA (1975) Process Design Manual for Nitrogen Control, Office of Technology, Washington D.C.

2. Tchobanoglous, G.and F. Urton, (2003) Wastewater Engineering: Treatment and Disposal. Mc Graw-Hill. 4th Edn..

3. Ershov, A.V., (1984) Use of transcarpathin clinoptilotic rock to remove Ammonium nitrogen from municipal sewage, Khim Tekhnol - Vody, 6, 71-75.

4. Haralambous. A., Maliou E., and Malamis M. (1992) The use of zeolite for Ammonium uptake, Water Sci. Tec., 25(1), 139-145.

5. Kazemian, H., (1993) Chemical analysis, characterization, and determination of Ion-Exchange properties of an Iranian natural zeolites, M.Sc. Thesis, Chem. Dep. Sci. Fac. Isfahan University, Isfahan, Iran

6. Rahmani, A. R.,. Mahvi A.H. and Mesdaghinia A.R., (2004) Investigation of Ammonium removal from polluted water by Clinoptilolite zeolite, International Journal of Environmental Sci. Tec., 1(2), 131-141.

7. Celik M.S., Ozdemir B., Turan M., Koyuncu I., Atesok G. and Sarikaya H.Z., (2001) Removal of ammonia by natural clay minerals using fixed and fluidized bed column reactors, J. Water Sci. Tec., 1(1), 81-88.

8. Ahmet Demir, Ahmet Gunay and Eyyup Debik, (2002) Ammonium removal from aqueous solution by ion exchange using packed bed natural zeolite, Water SA, 28(3), 329-335.

9. Ori Lahav and Michal Green, (1998) Ammonium removal using ion exchange and biological regeneration, J. Wat. Res., 32,(7), 2019-2028.

10. Semmens M.J., and Goodrich R., (1977) Biological regeneration of ammonium - saturated Clinoptilolite, J. Environmental sci. Tec., 11(3), 255-268.

11. Semmens M.J., Wang J.T. and Booth A.C., (1977) "Nitrogen removal by ion exchange: Biological regeneration of Clinoptilolite ,J. WPCF, 49(12), 2431-2444.

12. Semmens M.J., and Porter P.S., (1979) Ammonium removal by ion exchange: using biologically restored regenerant, J. WPCF, 51(12), 2928-2940.

13. Rahmani, A.R., Mesdaghinia A.R. and Mahvi A.H., (2003) Applied of Ion Exchange and Nitrification processes in Ammonium removal from polluted water in batch system, Wat. Wastewater J., 44, 38-45.

14. Clesceri, L.A., Greenberg E. and Eaton A.D., (1998) Standard Methods for the Examination of Water and Wastewater, APHA, AWWA, WEF, $20^{\text {th }} \mathrm{Ed}$. 